\title{
AN INNOVATIVE FINANCING INSTRUMENT TO PROMOTE THE DEVELOPMENT OF ISLAMIC MICROFINANCE THROUGH SOCIALLY RESPONSIBLE INVESTMENT SUKUK
}

\author{
Mohamed Yassine Khouildi ${ }^{1}$ and Salina Hj. Kassim ${ }^{2}$ \\ ${ }^{1}$ International Islamic University Malaysia (IIUM), Malaysia. \\ Email: yassine.khouildi@gmail.com \\ ${ }^{2}$ International Islamic University Malaysia (IIUM), Malaysia. Email: ksalina@iium.edu.my
}

\begin{abstract}
Socially Responsible Investment (SRI) sukuk has a high potential to be an innovative financing mechanism for Islamic microfinance. This paper explores the possibility of implementing SRI sukuk for raising funds to support the microfinance industry and to promote financial inclusion. It also aims to identify the associated issues and challenges in implementing the SRI sukuk for microfinance purpose. The paper uses qualitative research method through a thorough review of existing literature, archives, and library research related to the area of social, sustainable and responsible investment sukuk, Islamic microfinance and their related issues. The SRI sukuk has a high potential to be developed as innovative shariah-compliant mechanism as shown by Malaysian experience in issuing the SRI sukuk to develop socially-related projects including the educational and green energy sectors. The paper also highlights and learn from the successful experience of the European Bank for Reconstruction and Development in issuing the first microfinance bonds. The findings from this study provide inputs to the relevant stakeholders in implementing new financial tools to develop the social sector, especially Islamic microfinance in helping the poor and assist them to become economically independent. New innovative tools for raising funds in microfinance is highly needed to achieve sustainability of the microfinance industry.
\end{abstract}

Keywords: Islamic Finance; Social Finance; Sukuk.

JEL Classification: E44; G10; F50.

Received : September 26, 2018

Revised : October 08, 2018

Accepted : November 29, 2018 


\section{INTRODUCTION}

The real essence of Islamic finance is the achievement of Maqasid al-Shariah, specifically the preservation of life (nafs). This preservation is not only about the physical conditions of a human being but includes the environment and space in which the human being survives and performs all his worships to his Creator. This objective also includes ensuring financial sustainability for the poor to improve their life conditions. Consequently, Islamic finance aims for the development of the community from all aspects.

Today the Islamic financial industry is witnessing a remarkable double digit average growth annually to reach a total asset of USD1.9 trillion approximately (IFSB, 2017). With the sustained double-digit growth over the last decade, Islamic financial system has gradually becoming an important component of the global financial system. Despite its rapid growth, the development of Islamic finance was limited to its three main sectors: the banking sector is the main and largest component which contributed approximately $79 \%$ of the total industry, while the rest of the share is being contributed by the Islamic capital markets and takaful segments, each contributing $19.8 \%$ and $1.3 \%$, respectively (IFSB, 2017).

The high concentration on these sectors has resulted to the creation of a gap between Islamic finance's ideals and reality. In particular, the social sector has remained relatively under-developed as reflected by the sustainably high poverty rate in the Muslim countries. Recent studies have found that about $50 \%$ of the world's poverty incidences are happening in the Muslim countries, despite the fact that the total number of Muslims form only $24 \%$ of the globe's population (Mughal, 2018).

Being governed by the Islamic law (shari'ah), the ultimate objective of Islamic finance is achieving socio-economic justice and well-being among all members of the society. However, these objectives have yet to be realized through the current practice of Islamic finance, hence the urgent need to explore new areas of Islamic finance to achieve its real intrinsic establishment purposes. In this regard, the Socially Responsible Investment (SRI) is highly suitable and potential instrument to reduce the gap between the ideals and real practice of Islamic finance and expand the scope of Islamic finance to be more inclusive in nature. Through shariah-compliant financial instruments such as SRI sukuk, Islamic finance has the potentials to achieve multiple socio-economic objectives such as alleviating poverty among the low-income group, reducing illiteracy in the education field, improving health conditions among the community and taking care of the environment to achieve better standard of living for all the levels of the society.

The introduction of a new sukuk type that is sustainable, responsible, and socially impactful can be considered as innovation in the Islamic finance industry. The SRI sukuk is the combination of ethical investment through the issuance of sukuk which is the highest growing Islamic financial instrument. Currently, there were few issuances of SRI sukuk to promote sustainable development in various sectors such as educational, environmental, and health sector. 


\section{LITERATURE REVIEW}

\subsection{Developing the Social Sector through Socially Responsible Investment}

There seems to be no consensus on the specific definition of SRI, however, it is commonly described as an investment that is based on personal values more than financial decisions. Some refer to this type of investment as sustainable, others refer to it as responsible, and some refer to it as impactful. For this purpose, we have chosen the term SRI to reflect that type of investment which is based on social impact and sustainability more than financial decisions.

Similarly, Adam and Shauki (2012) adds that the term "SRI" has been widely used and often being described as an investment that will consider the impact of the investment in terms of ethics, social and environment. Some defined it as ethical, social and sustainable investment. The increasing demand over SRI made it the hot topic these days. The need for social development is a major reason for the high demand on SRI.

According to AAOIFI (2015), sukuk or Islamic bonds are basically certificates of equal value that represents undivided ownership of an assets, usufructs and services or (in the ownership of) the assets of particular projects or special investment activity. According to the MIFC, the global sukuk issuance has reached USD74.8 billion at the end of the year 2016. Among the highest sukuk issuer are Malaysia, USD34 billion, in which represents $46.4 \%$ of the global sukuk market, followed by (GCC) Countries that has a total issuances of USD19.6 billion (MIFC, 2017).

Zain and Sori (2017) argues that it is the best time for Islamic financial system to bridge the gap between the theory of Islamic finance and the practical side by innovating and adopting innovative tools such as SRI sukuk for the development of sectors other than the three main ones (Banking, Capital market, Takaful). It is a high time for Islamic financial institutions and authorities to implement the usage of SRI sukuk in the development of the microfinance industry as it has remained marginalized. The SRI sukuk can be implemented in a wide variety of fields and sectors, it is not only limited in the health and energy sector. In this regard, the Securities Commission Malaysia (SCM) (2017) has issued a guideline on the issuances of SRI sukuk. The guideline indicates that the issuer of the sukuk must utilize the proceeds raised form the issuance of socially responsible investment sukuk for financing and eligible project. The SCM defines two main requirements for projects in order to be considered as eligible SRI project. The first criteria is related to the goals and objectives of the project, meanwhile the second is related to the activities sector of the project.

According to SCM, a SRI project must be having on or more of the following objectives. First, it concerns any project that aims to protect and preserve the environment and its natural resources. Second, any project that has an objective of conserving the consumption and utilization of energy. The third objective is designed for projects that are aiming to promote the utilization of renewable energy and reducing the gas emissions. The last objective concerns projects that are aiming to improve and ameliorate the quality of life among members of the society.

The eligible SRI projects must have activities or assets related to one or more specific sectors. The first sector is the natural resources related activities, mainly 
it is related to projects in which their activity is to promote or participate in the sustainable usage of lands as well as sustainable agriculture and forestry or any related activity. Also, it includes all activities that conserve the biodiversity of the planet. The natural resource sector is even extended to the redevelopment of polluted sites, water treatment and recycling as well as the sustainable projects that are aiming to sustainably manage the wastes.

The second sector of eligible SRI projects is the renewable energy and energy efficiency related assets or projects mainly an existing or new renewable energy project such as solar energy or hydropower. Additionally, efficient energy projects consisting of efficient energy generation or energy that results in the reduction of energy consumption or reducing greenhouse gas emission. The statement is clear and includes all assets or activities related before mentioned projects.

The third sector of eligible SRI projects is more on any economic and community development related activities such as medical services (public hospitals). The activities of this sector are wide and include also any services related to public education and other community services. Additionally, all activities aiming to develop the social sector such as building sustainable projects or the contribution in the supply of affordable housing for low income part of the society.

The last sector of SRI eligible projects is the waqf (endowment) activities. This includes any project which undertakes to develop a waqf asset or property. The above guideline represents a regulatory framework which is certainly beneficial especially for promoting the progression of the sukuk caused by the growing awareness and demand of investors and institutions towards SRI projects. Until today the issuances of sukuk didn't is still concentrated on funding giant projects rather than the development of social sector.

Mohamad, Lehner and Khorshid (2016) have criticized the Islamic finance for its lack of participation in promoting financial inclusion and the social welfare for the poor. The authors also highlight the exclusion of the social sector in terms of the innovative products and services. The weakness of the Islamic finance is being witnessed through the underdeveloped social sector within Muslim countries which suffers from high poverty, illiteracy, unemployment and lack of social welfare. The authors highlight there is a need for innovative shariah compliant tools for the social sector.

\subsection{The Experience of European Bank for Reconstruction and Development in Issuing Microfinance Bonds}

As a reference, the essence of SRI sukuk for financing the microfinance sector can be extracted from the conventional counterpart known as microfinance bond or social impact bond (SIB) issued by the European Bank for Reconstruction and Development (EBRD). Since 2010 the EBRD has issued bonds worth of EUR 174 million to be used for financing micro-projects (EBRD, 2017). Targeting a large type of investors, the EBRD was successful in meeting some of the objectives of the issuances in terms of improving the life conditions, providing activities that generates revenues, and expanding some small projects. Table 1 lists some general information about some previous issuances of microfinance bonds in different geographical areas. 
Table 1.

European Bank for Reconstruction and Development Microfinance Bonds Issuances

\begin{tabular}{lcc}
\hline & South African Currency & Mexican Currency \\
\hline Amount & ZAR 726 million (EUR77 million) & MXN 1.7 billion (EUR98 million) \\
Issue date & $14 / 06 / 2010$ & $15 / 12 / 2015$ \\
Maturity date & $23 / 06 / 2013$ & $15 / 12 / 2015$ \\
Coupon & $6.7 \%$ semi-annually & $5.08 \%$ annually \\
Redemption price & $100 \%$ & $100 \%$ \\
\hline
\end{tabular}

Source: European Bank for Reconstruction and Development (2017)

In the prospectus of the following issuances, the EBRD have highlighted "Proceeds of the bonds support the development of micro and small enterprises in the EBRD's countries of operations". Some of the proceeds of the following where bonds were used in the following:

Table 2.

Global Issuances of European Bank for Reconstruction and Development Bonds for Microfinance

\begin{tabular}{lcccc}
\hline & Tajikistan & Kazakhstan & $\begin{array}{c}\text { Bosnia and } \\
\text { Herzegovina }\end{array}$ & Serbia \\
\hline Amount & USD4 million & USD11.5 million & EUR6 million & EUR5 million \\
\hline Local Partner & FINCA & Bank Center Credit & $\begin{array}{c}\text { Micro Credit } \\
\text { Foundation }\end{array}$ & Banca Intesa A.D \\
\hline $\begin{array}{l}\text { Sector of } \\
\text { Activities }\end{array}$ & Animal husbandry & Diversified & Agriculture & Diversified \\
\hline Purpose & Develop rural areas & $\begin{array}{c}\text { Support women-led } \\
\text { micro and small } \\
\text { projects }\end{array}$ & $\begin{array}{c}\text { Develop } \\
\text { microfinance } \\
\text { industry in the } \\
\text { country }\end{array}$ & $\begin{array}{c}\text { Support women-led } \\
\text { micro and small } \\
\text { projects }\end{array}$ \\
\hline
\end{tabular}

Source: European Bank for Reconstruction and Development (2017)

The issuance of the bond was for funding sustainable projects. Table 2 illustrates the utilization of the funds where EBRD provides a loan to one of its local partners to finance micro and small enterprises. As the local partner has the database of the enterprises in need of funds, it makes the task easier to channel the funds. The proceeds from a single bond can be utilized in various geographical areas to diversify the risk also to promote financial inclusion in an international level.

On domestic level microfinance industry has witnessed several bond issuances which couldn't reach international markets due to the non-development of the local capital markets. According to Rhyne and Reddy (2006), microfinance institutions usually approach the domestic markets for fund raising for several reasons. Mainly, the raised fund will be in local currency which will reduce costs and will mitigate the currency risk. Another factor is that domestic market players are familiar with the local microfinance industry and in some occasions, they might be aware of the MFI specific activities. Additionally, the local investors might see microfinance as 
attractive investment because of the few investments offered to local investors. Finally, the international markets are more oriented towards funding in large level in which this is not the case for majority of microfinance institutions.

Rhyne and Reddy (2006) have highlighted several domestic bonds issued by microfinance institutions. The three following issuances were all issued on domestic level in Latin America due to their high need for developing the microfinance sector.

\subsubsection{Compartamos}

The first was the Compartamos MFI which is a Mexican finance company which was looking for new investors to target rather than depending uniquely on two major sources of fund, the foreign lenders or the credit lines with the Mexican banks. Table 3 illustrates the total issues at that time along with their ratings and the investors which subscribed to the bonds and other relevant features of the bond.

Table 3.

Compartamos Microfinance Bond Issues

\begin{tabular}{|c|c|c|c|c|c|c|}
\hline Issue & Year & $\begin{array}{l}\text { Amount } \\
\text { (USD mil) }\end{array}$ & Coupon & $\begin{array}{l}\text { Tenor } \\
\text { (years) }\end{array}$ & Rating & Investors \\
\hline \multirow[t]{2}{*}{1} & 2002 & 1 & 90 days & 3 & $\mathrm{MX}^{4} \mathrm{~A}+$ & Individual (70\%) \\
\hline & & & CETES $^{3}+250 \mathrm{bp}$ & & & Institutional (30\%) \\
\hline \multirow[t]{2}{*}{2} & 2002 & 5 & 90 days & 3 & MX A+ & Individual (50\%) \\
\hline & & & CETES + 250bp & & & Institutional (50\%) \\
\hline \multirow[t]{2}{*}{3} & 2003 & 5 & 90 days & 3.25 & MX A+ & Individual (100\%) \\
\hline & & & CETES + 290bp & & & \\
\hline \multirow[t]{2}{*}{4} & 2004 & 16.6 & 28 days & 5 & MX AA & Individual (60\%) \\
\hline & & & $\mathrm{TIIE}^{5}+150 \mathrm{bp}$ & & & Institutional (50\%) \\
\hline \multirow[t]{2}{*}{5} & 2005 & 31 & 28 days & 5 & MX AA & Individual (30\%) \\
\hline & & & TIIE $+117 b p$ & & & Institutional (70\%) \\
\hline
\end{tabular}

Source: Presentations by Rafael Llosa (Mibanco), Fernando Alvarez Toca (Compartamos), Clara Serra de Akerman (WWB), and the Small Enterprise Development Journal "The Financing of Microfinance" March 2005 adopted from (Rhyne \& Reddy, 2006)

It is observable in Table 3 that the amounts of issuance have increased significantly, also the institutional investors are increasing to reach $70 \%$ from total investors. The institutional investors' interest on such issuances is a positive sign to promote the growth of microfinance sector and to reduce the gap between the private sector and the social sector. Interestingly, Standard \& Poor's (S\&P) rated the bond using national Mexico scale because they assume that investors will be Mexican because this was issued on a domestic level was given a rate of $\mathrm{A}+$ on first three issues then AA for the next two issues.

\footnotetext{
3. Mexican Federal Treasury Certificates

4. National Mexico scale for rating

5. Interbank Equilibrium Interest Rate
} 


\subsubsection{Mibanco}

Another domestic issuance in Latin America but this time in Peru, Mibanco which is a commercial bank anted to diversify the sources of funds and on the same time to obtain a longer tenor and better rates. According to Rhyne \& Reddy (2006) argues that this initiative was aiming to change the investors wrong perception about the level of risk in microfinance industry. Table 4 illustrates the general features of the Mibanco bond which was issued in a program of three issues.

Table 4.

Mibanco Microfinance Bond Issues

\begin{tabular}{|c|c|c|c|c|c|c|}
\hline Issue & Year & $\begin{array}{l}\text { Amount } \\
\text { (USD mil) }\end{array}$ & Coupon & $\begin{array}{r}\text { Tenor } \\
\text { (years) }\end{array}$ & Rating & Investors \\
\hline 1 & 2002 & 5.8 & $12 \%$ & 2 & AA \& AA & $\begin{array}{l}\text { Pension funds ( } 83 \%) \\
\text { Mutual funds }(17 \%)\end{array}$ \\
\hline 2 & 2003 & 5.8 & $12 \%$ & 2.25 & AA \& AA & $\begin{array}{c}\text { Pension funds (26\%) } \\
\text { Mutual funds (33\%) } \\
\text { Public entities (29\%) } \\
\text { Banks (10\%) } \\
\text { Insurance companies (3\%) }\end{array}$ \\
\hline 3 & 2003 & 2.9 & $5.75 \%$ & 1.5 & AA- \& A+ & $\begin{array}{l}\text { Pension funds (20\%) } \\
\text { Mutual funds (21\%) } \\
\text { Public entities (59\%) }\end{array}$ \\
\hline
\end{tabular}

Source: Presentations by Rafael Llosa (Mibanco), Fernando Alvarez Toca (Compartamos), Clara Serra de Akerman (WWB), and the Small Enterprise Development Journal “The Financing of Microfinance” March 2005 adopted from (Rhyne \& Reddy, 2006)

Fernando \& Calcetas (2003) highlights that with a guarantee of $50 \%$ by the US Agency for International Development (USAID), the first bond in 2002 was issued for approximately $\$ 6.0$ million. This latter was totally purchased by the private sector by pension and mutual funds, but interestingly that public entities and banks started subscribing to the second issues. After these issues Mibanco continued to issue other bonds and other capital market instruments.

\subsubsection{WWB Cali}

Women's World Banking Cali is a nonprofit microfinance institution in Colombia in which it aimed to diversify its sources of funds and to get some long-term financing, for this purpose this unregulated microfinance institution found bond as a better solution. Table 4 illustrates the general features of the WWB Cali bond which was issued in a program of three issues. 
Table 4.

WWB Cali Microfinance Bond Issues

\begin{tabular}{|c|c|c|c|c|c|c|}
\hline Issue & Year & $\begin{array}{l}\text { Amount } \\
\text { (USD mil) }\end{array}$ & Coupon & $\begin{array}{l}\text { Tenor } \\
\text { (years) }\end{array}$ & Rating & Investors \\
\hline \multirow[t]{3}{*}{1} & 2005 & 20 & $10.78 \%$ & 3 & $\mathrm{AA}+$ & Pension funds (31\%) \\
\hline & & & & & & Financial institutions (24\%) \\
\hline & & & & & & Brokers $(37 \%)$ \\
\hline 2 & 2005 & 10 & $\mathrm{CPI}^{6}+5.5 \%$ & 5 & & Others $(8 \%)$ \\
\hline \multirow[t]{4}{*}{3} & 2005 & 22 & $\mathrm{CPI}+3.4 \%$ & 6 & $\mathrm{AA}+$ & Pension funds (17\%) \\
\hline & & & & & & Financial institutions ( $42 \%)$ \\
\hline & & & & & & Trust funds (19\%) \\
\hline & & & & & & Others $(22 \%)$ \\
\hline
\end{tabular}

Source: Presentations by Rafael Llosa (Mibanco), Fernando Alvarez Toca (Compartamos), Clara Serra de Akerman (WWB), and the Small Enterprise Development Journal "The Financing of Microfinance" March 2005 adopted from (Rhyne \& Reddy, 2006)

The successful issuance of microfinance bond by WWB Cali opened the door of Colombian capital market for microfinance institutions to issue financial instruments for raising funds. The proceeds of this issuance will be utilized to finance micro projects aiming to develop the local microfinance industry. The lessons that can be taken from such successful issuances and how their impact is not only on the economy but also the society and for this reason this type of securities has a primary objective of social development. Hence, it is the time for Islamic financial providers to work on bridging the gap between the theory and practice by the development of such tools.

\section{METHODOLOGY}

This paper adopts the qualitative method which is basically based on previous literatures and archives as well as library research to collect data. The main source of information is generated from secondary data which is composed of previous published articles related to sukuk and microfinance. In addition, the paper uses case studies method through studying previous cases of conventional bonds in microfinance. The purpose of collecting the secondary data is to identify the gap between the literatures and the current possibility of the issuance of Social responsible investment sukuk for microfinance adoption of salam as an alternative to tawarruq for Malaysian banks.

\section{RESULTS AND FINDINGS}

Among the financial tools that have been derived from SRI concept are Social Impact Bonds (SIBs) and Socially Responsible Investment (SRI) sukuk, however this latter is set to be as a form of SIB that is arranged using a combination of shari'ah based contracts; but nonetheless they share the same commitments towards better

6. Consumer Price Index in Columbia 
social outcomes, as well as some commonalities such as the result-based approach since the returns are paid in accordance to the success of the programs.

During the past few years, there are several SRI sukuk issuances in several sectors; the first one was sukuk Ihsan in 2015 in the educational sector. The second one was by the World Bank along with the International Finance Facility for Immunization which was issued in 2015 to develop the health sector, while the third one is Tadau sukuk issued in Malaysia in 2017 for the purpose of providing green energy. The above-mentioned issuances show that SRI sukuk are not limited a specific sector, but it can be widely issued as long as it has the objective of social development.

As sukuk has been always an efficient tool to raise funds for projects, then there is potential to use sukuk for raising funds in order to financing micro projects. An important question arises about the eligibility of the microfinance institution to attack the capital markets through the issuance of an Islamic or conventional bond and the possibility to approach markets. In this regard, Otero (2006) argues that not all MF institutions are eligible or ready to attack the capital markets. There are some newly established institutions which they still need more technical support or guarantee to improve their day to day operations and governance. On the other hand, there are other microfinance institutions sitting at the top end of the industry where they are attractive to investors as well as their ability to absorb investments on competitive commercial terms. The stability and reputation of the microfinance institution plays and important role in easing the path for the accessibility to the capital markets.

The origin of this type of investment goes far back in history such as the non-participation of slave trading, but only in the $20^{\text {th }}$ century it was recognized as an investment strategy and especially during the last two decades it developed significantly in size. Recently, there has been a growing interest in the global market toward SRI instruments. It has shown an upward growth over the past decade. According to Mujahid and Adawiah (2015) the total assets of socially responsible investments in the United States was estimated around USD 6.57 trillion while USD 90 billion in the UK as of 2014. In western countries, social impact bonds (SIB) is an example of a highly used financial tool.

\subsection{Proposed Model}

Since bond is not in compliance with shariah principles, then sukuk is the alternative to be issued for such purpose. The paper suggests a simple model based on Mudarabah (profit sharing) that can be issued by a microfinance institution in order to raise funds for financing micro and small projects that are in compliance with shariah. Figure 1 below illustrates the movement of funds raised by the issuance of SRI sukuk in microfinance. 


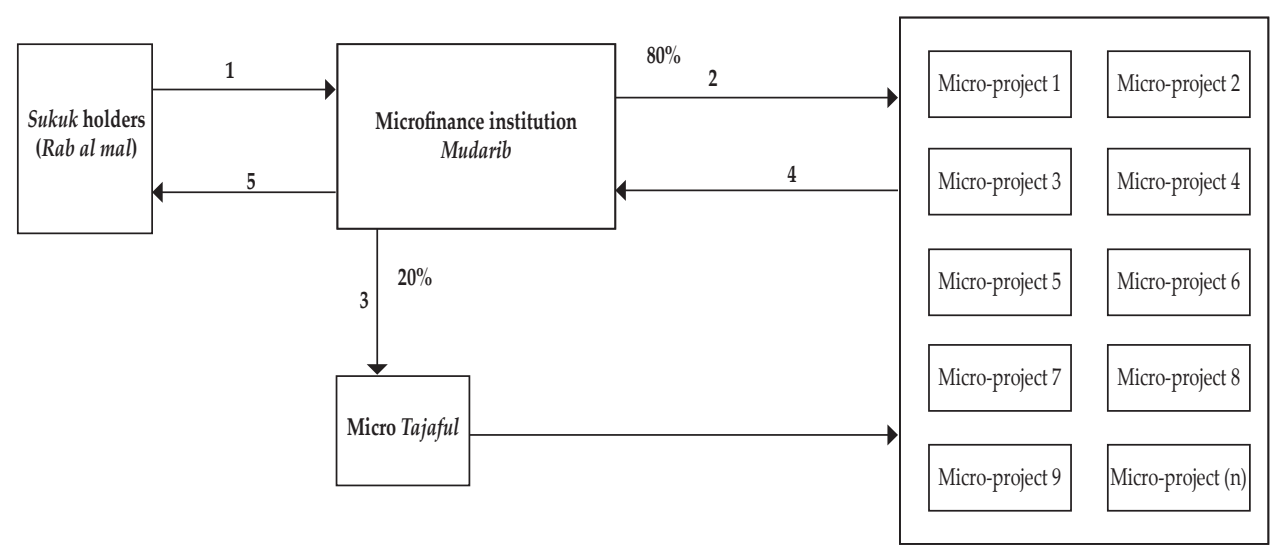

Source: Authors' own.

Figure 1. Proposed Generic Sukuk Model for Microfinance

The unique aspect of this socially responsible investment sukuk is that it is basically a type of investment that is based on personal and social values more than financial values. Nowadays, there is a need for value-based investments to bridge the gap between all sectors of the economy and society. Some authors consider that investing in microfinance "belongs to the realm of socially responsible investment" (Galema, 2011).

Socially Responsible Investment (SRI) sukuk is a financial instrument that has a primary objective of developing the social sector as well as the protection of the environment. Different from other financial instruments, SRI sukuk is not only driven by profitability but mainly driven by values and ethics. Like any other sukuk, investors in the SRI sukuk will subscribe to an issued certificate where it represents an undividable ownership in a specified project. As the projects goes on investors will be receiving periodic profits (coupons) based on the performance of the project, however by the end of the project investors will be paid based on their shares or at any pre-agreed terms and conditions.

Microfinance exists in the heart of socially responsible investments, while sukuk stands as the most trending Islamic capital market instrument. Today there is the possibility of having a sukuk issuance in which the funds raised will be used to finance micro projects through a microfinance institution. The funds raised by the issuance of the SRI sukuk will be utilized by a reputable and well governed microfinance institution on the bases of partnership where it carries the responsibility to finance micro project. However, the microfinance institution will carry additional duties such as supervision and monitoring the financed projects as well as there will be some campaigns organized to improve entrepreneur's' management skills. This type of financing will promote risk sharing financial transactions rather than the total dependence on debt-based financing.

In SRI sukuk, the proceeds of the issuance of the sukuk must be invested, utilized, or applied in a specific assets or purposes that are in compliance with the rules and principles of shariah. The purpose of the issuance must be clear and 
predefined rather than unspecified or general purposes. Additionally, income from the certificates sukuk (periodic profit) must be generated from the purpose of the issuance since sukuk are based on underlying assets that are real. As mentioned before the sukuk represents an undividable ownership over specified assets. The rights of ownership of the assets are transferred to the sukuk holders for a fixed period in which it ends upon the maturity date of the sukuk.

In summary there are several steps involved in the issuance of the above illustrated SRI sukuk for Islamic financial institution. The first step is the issuance of the sukuk certificate by the microfinance institution in which investors will subscribe into, then investors will be considered as sukuk holders while MFI institution is the obligor. The relationship between both parties will be based on partnership and specifically under the shariah contract of Mudarabah. Then the proceeds of the issuance will be utilized mainly for two purposes, $80 \%$ (as an example) of the funds raised in order to finance the micro projects. Financing will be on the bases of several contracts depending on the nature of the project for example Murabahah for some financing facilities (cash), Salam for agricultural financing (olives), Ijarah for machineries (tailoring). The other $20 \%$ of the raised fund will be utilized by the microfinance institution for the protection of the micro enterprises through participation in micro-takaful fund where by this will mitigate the risk of micro projects and this might be a source of an additional income for investors in case of surplus in the takaful fund.

After the micro projects starts operating, their managers will start paying periodic profits to the microfinance institution (mudarib) upon a pre- agreed ratio (ex: $70 \%-30 \%$ ). Additionally, the micro projects managers will start paying the asset redemption amount to the sukuk holders. This is for the micro projects managers to own the projects at the end of the day (the redemption remains with the Microfinance institution until maturity and then redeems it on one time to the sukuk holder). Finally, the microfinance institution will be paying periodic profits to the sukuk holders and at maturity it will be paying the redemption amount.

\section{CONCLUSION}

With the objective of exploring the viability of issuing an SRI sukuk to serve as a financial tool for financing projects at a micro level, this paper finds that there are potential for the issuances of the SRI sukuk in microfinance due to availability of the legal infrastructure that supports the issuance also to the high demand for such products by investor. The benefits that can be obtained through raising funds through sukuk for financing micro projects are unlimited, and this was proven throughout the last years, the several issuances of SRI sukuk have been witnessing a positive impact on the society even before maturity.

The paper recommends that more attention should be given to the development of the social sector rather than private sector due to the high need for innovative products promoting financial inclusion as well as the development of social sector in all its aspects to achieve Maqasid al Shariah. In this regard, SRI sukuk is seen as a financial instrument that can positively contribute in achieving these maqasid. According to Zain \& Engku (2017), SRI sukuk can be utilized to develop and protect and preserve the religion (deen) through the protection of the present and future of 
the society and its members. The alleviation of evil (mafsadah) and the important consideration of public interest (maslahah) is a primary objective of Islam where it is clear and comprehensive about this. Moreover, the authors give microfinance as an example of protection of life (nafs), when a micro-credit is given without interest, this will eventually create business opportunities which will result in the creation of additional jobs for other members of the society. This process will lead to lower unemployment rates and this is the essence of Islamic social finance.

The SRI sukuk for microfinance is not an ordinary financial instrument for several reasons. The funds raised will promote to financial inclusion while on the same time it will be generating profits for the investors. The microfinance institution plays an important role due to its database that contains a list of micro projects that have been studied but due to the lack of financing the projects couldn't take place. Moreover, the existing databases will reduce the cost of feasibility study because the projects have been already studied by the MFI previously. Another important role is being played by the takaful institution in providing coverage for the micro projects and this will result to more profitable business.

In addition, there are several advantages of issuing such sukuk in microfinance. The issuance of such sukuk will result in more contribution to the economic sector and will give the opportunity to micro projects to participate significantly to the economic activities. It should be highlighted that around the world, a huge quantity of skills are being buried due to the lack of financing. Microfinance institutions are suffering for the lack of resources to satisfy the need of the poor to engage in economic activities. The ability of financing micro projects will promote to the development of the financial and economic sector by increasing the output of the society, this will result in increasing the GDP. Rachmawati (2015) found out that the micro enterprises have contributed in around 36\% of the GDP growth in 2012.

Another advantage of this issuance is the promotion a better risk sharing environment between stake holders. As SRI sukuk in microfinance is a combination of the private, public and third sector in economic activities. The sharing of risk between the economic sectors will reduce the amount of risk for each party. The private sector is composed of institutional investors, while the public sector is the support provided by the government. Mohamad et al. (2016) add that this will result in decreasing the government spending which will result in decreasing government's debt.

Moreover, SRI sukuk will act as an innovative financial instrument for social finance. SRI sukuk in microfinance will act as an alternative to traditional existing financing tools which are missing the lack innovation and diversity of financing products especially the excessive dependence and use of debt financing as sukuk in the essence represents a financial tool that is based on equity. At micro level the financial instruments are very limited as well as the resources.

Finally, it will lead to a new alternative asset class that might be more attractive some of the existing ones. this has been highlighted by Mohamad et al. (2016) that securitization of social programs is a highly need asset class and such initiative is a push towards the creation of alternative asset classes for investment in for Islamic capital markets. One of the challenges for Islamic financial system is the lack of financial instruments especially for Islamic capital market. The lack of innovation is acting as a hindrance to the growth of the system. For this purpose, the SRI sukuk 
can be an alternative asset class and can target a large potential of investors that have the intention of social development as well as lucrative objectives. However, Rhyne and Reddy (2006) argues that microfinance is still facing some challenges to be considered as a good asset class. The authors highlight that for microfinance industry to be attractive asset class it should have the following characteristics. First and most important, the microfinance institution must have an appropriate risk and return profile to attract investors. Second, there should be a ready and easy access to all information related to risk-return similarly with the stock market. The third characteristic is to have suitable scale to cover investing costs and to be able to generate profits. Last but not least, there should be easy entry and exit from the securities and this aims to make microfinance as a highly liquid asset class.

Notwithstanding that with all the sustainable potentials offered by SRI sukuk mentioned above, a number of hindrances can jeopardize their steady development, perhaps the easily spotted constrains is the small size of the secondary market, mainly caused by the modest number of private and institutional investors who operates with sukuk funds, and consequently are in need of players to boost the secondary market, in order to meet their liquidity expectation (MIFC, 2016). Perhaps the most adverse challenge is no other than the absence of standardization and the establishment of a verification system for performance measurement not only for sukuk but all the SRI bonds; even with the existence of various voluntary guidelines. The sukuk industry is already struggling to keep pace with the rapidly changing regulatory environment, and the process of reaching consensus among governments, investors and the sukuk's shariah boards is taking significantly long (Natoor, 2017).

This last issue if it is not dealt with can incur more negative consequences, because without standardization, investors have no reassurance other than the reputation of the company, that the proceeds of the endeavor will be used for projects with economic value, while at the same time meeting accepted and credible green standards. add to that the high risk profile associated with some SRI sukuk like the ones venturing in the energy sector, since it involve a sophisticated degree of new technology with no precedent to fairly control the risks involved (Mcaughtry, 2015).

\section{REFERENCES}

AAOIFI. (2015). AAOIFIShariah Standard 2015. Washington, D.C: The International Bank for Reconstruction and Developement/The World Bank.

Adam, A. A., \& Shauki, E. (2012). Socially Responsible Investment in Malaysia: Behavioural Framework to Evaluate Investors' Decision - Making Process. International Graduate School of Business Journal, 80(2), 224-240.

Azman, S. M. M. bin S., \& Engku, E. R. A. (2015). Sustainable and Responsible Investment (SRI): Trends and Prospects. Kliff, (December).

Azman, S. M. M. bin S., \& Engku, E. R. A. (2016). Potential Role of Social Impact Bond and Socially Responsible Investment Sukuk as Financial Tools that Can Help Address Issues of Poverty and Socio-Economic Insecurity. Intellectual DIscourse, Special Issue IIUM Press, 4878, 343-364. 
EBRD, E. B. for R. and D. (2017). EBRD Microfinance Bond.

Fernando, N. A., \& Calcetas, P. P. (2003). Mibanco, Peru: Profitable Microfinance Outreach, with Lessons for Asia. Asian Development Bank, (July).

Galema, R. J. (2011). Microfinance as a Socially Responsible Investment. University of Groningen, Groningen, The Netherlands. Retrieved from https://www. netspar.nl/assets/uploads/019_PhD_Rients_Jan_Galema.pdf

IFSB. (2017). Islamic Financial Services Industry Stability Report. Islamic Financial Services Industry. Kuala Lumpur. Retrieved from http://www.ifsb.org/sec03. php

Mcaughtry, L. (2015). The Global Leader in Islamic Finance Has Its First Financial Hub. Islamic Finance News, 1-124. Retrieved from https://islamicfinancenews. com/2015_supplement/guide/IFNGuide.pdf

MIFC. (2017). 2016 Global Sukuk Market : A Record Year for Corporate Issuance.

MIFC, M. I. F. C. (2016). Sri E Green Sukuk: Challenges \& Prospects. Retrieved from http://www.mifc.com/index.php?ch=28\&pg=72\&ac =162\&bb=uploadpdf

Mohamad, S., Lehner, O., \& Khorshid, A. (2016). A Case for an Islamic Social Impact Bond. ACRN Oxford Journal of Finance and Risk Perspectives, 52, 65-74. Retrieved from http://www.acrn-journals.eu/resources/jofrp0502e.pdf

Mughal, M. Z. (2018). Poverty in Muslim World is Rapidly Increasing. Retrieved February 16, 2018, from http://www.alhudacibe.com /imhd/news22.php

Natoor, B. Al. (2017). Why Green Sukuk Could be a Growth Driver for Islamic Finance. Retrieved May 27, 2018, from https://medium.com/fitch-blog/whygreen-sukuk-could-be-a growth-driver-for-islamic-finance-d6881f592f5c

Otero, M. (2006). Who Will Buy Our Paper: Microfinance Cracking the Capital Markets? In The Realities of Linking Microfinance to Local E International Capital Markets. ACCION International.

Rachmawati, D. E. (2015). Market Opportunities and Regulations Microfinance in Indonesia. Journal of East Asian Studies, 3(13), 173-194.

Rhyne, E., \& Reddy, R. (2006). Who Will Buy Our Paper: Microfinance Cracking the Capital Markets? ACCION International's InSight Series, April, (18). Retrieved from http://papers.ssrn.com /sol3/papers.cfm?abstract_id=901260

SCM. (2017). Guidelines On Issuance Of Corporate Bonds And Sukuk To Retail Investors. Retrieved from https://www.sc.com.my /wpcontent/uploads/eng/html/ resources/guidelines/bondmkt/guidelines_retailsPDS_sukuk_171108.pdf

Zain, N. R. M., \& Engku, E. R. A. (2017). An Analysis on Islamic Social Finance for Protection and Preservation of Maqāṣ id al- Sharī'ah. Journal of Islamic Finance, 2117(Special issue), 133-141.

Zain, N. S., \& Sori, Z. M. (2017). An Exploratory Study on Ijarah Sri Sukuk for the Development of Waqf Properties/Assets in Malaysia. International Centre for Education in Islamic Finance (INCEIF), (October). Retrieved from https://www. researchgate.net/publication/320546014 